ECOLOGICA, Vol. 28, No 104 (2021), 557-564

https://doi.org/10.18485/ecologica.2021.28.104.10

Originalni naučni rad

UDC: $33:[616.98: 578.834](497.11)$

\title{
Mala i srednja preduzeća na udaru COVID cunamija
}

\section{Small and medium-sized enterprises are hit by COVID-19 "tsunami"}

\author{
Marko Todić ${ }^{1 *}$, Nenad Milić ${ }^{2}$ \\ ${ }^{1}$ Univerzitet u Prištini s privremenim sedištem u Kosovskoj Mitrovici, Ekonomski fakultet, Kolašinska 156, \\ 38220 Kosovska Mitrovica / \\ University of Prishtina with temporary headquarters in Kosovska Mitrovica, Faculty of Economics, \\ Kolašinska 156, 38220 Kosovska Mitrovica \\ 2Univerzitet Singidunum, Departman za poslediplomske studije i međunarodnu saradnju, Beograd, Srbija / \\ Singidunum University, Department of Postgraduate Studies and International Cooperation, Belgrade, Serbia \\ ${ }^{*}$ Autor za prepisku / Corresponding author
}

Rad primljen / Received: 08.09.2021, Rad prihvaćen / Accepted: 03.11.2021.

Sažetak: Kriza izazvana pandemijom COVID -19 imaće brojne nesagledive posledice po svetsku i privredu Republike Srbije. Kako će srpska privreda i preduzeća "preležati" virus - potpuno je neizvesno. Izvršeno istraživanje razmatra nekoliko ključnih aspekata problema s kojima se suočavaju mala i srednja preduzeća u Republici Srbiji u uslovima krize. Pandemija COVID-19 izazvana virusom SARS-2 osim uticaja na živote i zdravlje ljudi, ima i razarajuće dejstvo na poslovanje preduzeća na globalnom i nacionalnom nivou. Cilj rada je utvrditi na koji način i u kojoj meri je pandemija COVID-19 uticala na poslovanje preduzeća i koji su najveći izazovi i problemi sa kojima se ona suočavaju. Osnovna hipoteza od koje se polazi je: Aktuelna pandemija je uslovila značajan pad profita i uticala na način poslovanja malih i srednjih preduzeća u Republici Srbiji. Analize u radu bile su sprovedene deskriptivnim metodom uz korišćenje naučne literature, publikacija a takođe anketnim istraživanjem i statističkom obradom podataka. Na osnovu sprovedene analize, metodom sinteze i komparacije izvedeni su zaključci. Istraživanje je pokazalo da pandemija COVID-19 ima negativan uticaj na preduzeća, na njihovo finansijsko poslovanje, a najviše su pogođena mala preduzeća.

Ključne reči: pandemija COVID -19, poslovanje preduzeća, recesija, profitabilnost, posledice.

\begin{abstract}
The crisis caused by the COVID-19 pandemic will have numerous unforeseeable consequences for the world economy and the economy of the Republic of Serbia. How the Serbian economy and companies will "spread" the pandemic is completely uncertain. The conducted research considers several key aspects of the problems faced by small and medium enterprises in the Republic of Serbia in the conditions of crisis. The pandemic caused by the COVID-19, in addition to affecting people's lives and health, also has a devastating effect on the company's business on a global and national level. The aim of this paper is to determine in what way and to what extent the COVID-19 has affected the business of the companies and what are the biggest challenges and problems they face. The basic hypothesis from which we start is: The current pandemic has caused a significant drop in profits and affected the way small and medium enterprises operate in the Republic of Serbia. Analyzes in this paper were conducted by descriptive method using scientific literature, publications and survey research. Based on the conducted analysis, conclusions were drawn by the method of synthesis and comparison. Research has shown that the pandemic COVID-19 has a negative impact on companies, their finances and business, and small businesses are most affected.
\end{abstract}

Keywords: pandemic, COVID-19, business operations, recession, profitability, consequences.

\footnotetext{
10rcid.org/0000-0001-6009-5468, marko.todic1993@outlook.com

2orcid.org/0000-0001-6744-7083,nenadmilic89@gmail.com
} 


\section{UVOD / INTRODUCTION}

Oboljenje COVID-19 izazvano globalnim širenjem virusa (SARS-2) već drugu godinu redom pogađa zdravstveni i poslovni sistem kako u svetu tako i na našim prostorima. Pandemija je dostigla vrhunac u četvrtom talasu i dovela do kolapsa svetsku i domaću ekonomiju. Pandemija se svakako može smatrati negativnim egzogenim šokom čije se delovanje širi kroz ekonomski sistem izazivajući ekonomski pad i recesiju (Prašćević, 2020). Od potpunih do delimičnih ili privremenih gašenja fabrika, do prekida u lancima snabdevanja, otpuštanja radne snage, krize likvidnosti i finansijskih stresova, kompanije se već sada suočavaju sa značajnim ekonomskim posledicama i šokovima zbog COVID-19. Pandemija COVID-19 dovela je do prekida saradnje između pojedinih zemalja i zatvaranja granica između pojedinih država, čak i unutar Evropske unije, i unutar pojedinih država (Država Victoria u Australiji, pojedine provincije u Italiji i Španiji) (Jovanović, Ermakov, 2020). Odlučivanje u nepredvidljivim kriznim situacijama se ne zasniva na logici i iskustvu, već na intuiciji, što može dovesti do značajnog pada profita. Većina preduzeća je morala da se suoči s pandemijom vodeći računa o zaštiti zdravlja zaposlenih, a zapostavljene su metode i tehnike profitabilnog i održivog poslovanja. Svi resursi su sada preusmereni na suočavanje sa nikada pre viđenom krizom u svim privrednim sektorima, obrazovnom sistemu, zdravstvu, transportu, turizmu, sportu (Đurović et al., 2020). U vreme zdravstvene i ekonomske krize briga o ljudima predstavlja jednu od ključnih tema za osiguranje kontinuiteta poslovanja. Zbog toga je neophodno da se kompanija prilagodi ili donese nove politike i procedure rada. Inicijalni - zdravstveni šok izaziva šok ponude jer se zbog preduzimanja zdravstvenih mera zaštite prekidaju lokalni i globalni lanci proizvodnje (Čavrak, 2020). Fornaro i Wolf u svojoj makroekonomskoj analizi, pokazuju da šok na strani ponude i pad proizvodnje, vode u pad produktivnosti i pad tražnje (Fornaro, Wolf, 2020).

Mikro, mala i srednja preduzeća u Srbiji se suočavaju sa novim rizicima - kako finansijskim, tako i poslovnim. Neka velika preduzeća su profitirala i došlo je do preraspodele profita, dok mikro, mala i srednja preduzeća su osetila najveće posledice krize prouzrokovane pandemijom (Tripković et al., 2021). Kriza u preduzeću se mora na vreme prepoznati, kako bi se na vreme reagovalo, jer u suprotnom dolazi do galopirajućeg širenja krize po svim segmentima poslovanja i negativnih posledica na privredu u celini (Duvnjak, 2020). Prilikom analiziranja i upravljanja rizicima potrebno je razmatrati nekoliko različitih scenarija $i$ ishoda. Potrebno je analizirati sopstvenu situaciju u širem kontekstu - mestu u ekonomskom lancu, imajući u vidu mogući različit uticaj krize na pojedine industrije i sektore, (Radoičić, Arsić, 2021). Kako bi zaustavili negativan ekonomski scenario i sprečili nelikvidnost, mnoge države su usvojile različite pakete privremenih fiskalnih i monetarnih mera za pomoć privredi i građanima (Živković et al., 2020). Različite zemlje, su bile pogođene pandemijom virusa nejednako, pa su i reagovale na razne načine $u$ smislu politika za rešavanje ove krize (Hale et al., 2020). Potrebno je razdvojiti podršku privrednim subjektima od podrške građanima zaposlenim u tim privrednim subjektima, što svakako ima efekta i na konkretna privredna lica. Takođe, mere socijalne i zdravstvene politike bi trebalo da ostvare posebnu podršku svim ostalim građanima. Tu se pre svega misli na pravo na besplatno lečenje za vreme trajanja krize i na pomoć najsiromašnijim slojevima stanovništva. Kriza u preduzeću, koja vremenski dugo traje, negativno se održava na preduzeće bez obzira kom sektoru ono pripada (Duvnjak, 2018). Neophodni su novi poslovni modeli za rešavanje problema u vreme pandemije da bi bile eliminisane pretnje daljem poslovanju izazvane globalnim širenjem virusa Corona (SARS-2) (Jovanović, Nikolić Tošović, 2021).

\section{MATERIJALI I METODE / MATERIALS AND METHODS}

Cilj rada je utvrditi na koji način i u kojoj meri je pandemija COVID-19 uticala na poslovanje preduzeća i koji su najveći izazovi i problemi sa kojima se ona suočavaju. Osnovna hipoteza od koje se polazi je: Aktuelna pandemija je uslovila značajan pad profita i uticala na način poslovanja malih i srednjih preduzeća u Republici Srbiji.

Da bi se izvršilo prikupljanje podataka kreiran je upitnik koij elektronskim putem poslat rukovodiocima privrednih subjekata iz kategorije mikro, malih i srednjih preduzeća iz oblasti prerađivačke industrije. Anketni upitnik je kreiran sa ciljem da se ispitaju stavovi rukovodioca o uticaju COVID-19 na poslovanje privrednih subjekata. Ukupno je popunjeno 62 upitnika, od kojih su 48 upitnika bila u potpunosti popunjena. Istraživanje je sprovedeno u periodu od 03.03. do 10.04.2021. godine. $U$ istraživanje se krenulo sa namerom da u ovom radu bude uključen što veći broj rukovodioca kompanija, kako bi istraživanje na polju uticaja pandemije COVID-19 na poslovanje privrednih subjekata bilo relevantnije i realnije. Statistička obrada podataka urađena je u programu IBM SPSS Statistics. Podaci su prvo prikazani deskriptivno i to korišćenjem apsolutne i relativne učestalosti. Povezanost između dve kategorijske promenljive analizirana je primenom hi-kvadrat testa nezavisnosti, dok su statistički značajni rezultati grafički prikazani korišćenjem stubičastog klaster grafikona. 
Analiza značajnosti razlike stavova ispitanika, o pitanjima čiji su odgovori definisani petostepenom Likertovom skalom, analizirana je primenom jednofaktorske ANOVA različitih grupa sa naknadnim testovima, odnosno t testom za nezavisne uzorke, dok su statistički značajni rezultati grafički prikazani korišćenjem linijskog grafikona. Rezultati su smatrani statistički značajnim ukoliko je p vrednost bila manja od 0,05.

\section{REZULTATI I DISKUSIJA / RESULTS AND DISCUSSION}

Uzorak je činilo 48 preduzeća među kojima je bilo $72,9 \%$ preduzeća sa privatnim kapitalom, $12,5 \%$ sa državnim kapitalom kao i $14,6 \%$ sa mešovitim kapi- talom. U odnosu na veličinu preduzeća, $37,5 \%$ je mikro preduzeća sa do 5 zaposlenih, $27,1 \%$ je malih preduzeća sa do 50 zaposlenih i $35,4 \%$ je srednjih preduzeća sa do 250 zaposlenih. U odnosu na način poslovanja, $79,2 \%$ je preduzeća koje zapošljavaju radnike, dok je $20,8 \%$ preduzeća u kojima vlasnik radi samostalno sa članovima porodice.

Prvi deo upitnika odnosi se na osnovne podatke o firmi i načinu funkcionisanja tokom pandemije COVID-19. Ovaj deo upitnika se sastoji od sedam pitanja i stavovi ispitanika iskazani na ova pitanja su analizirani u odnosu na vlasništvo nad preduzećem, veličinu preduzeća kao i način poslovanja. Dobijeni rezultati su prikazani u Tabeli 1 .

Tabela 1. Osnovni podaci o načinu funkcionisanja tokom pandemije COVID-19

Table 1. Basic information on the function during pandemic COVID-19

\begin{tabular}{|l|c|c|c|c|c|}
\hline \multicolumn{1}{|c|}{ Pitanje } & \multicolumn{2}{|c|}{ Procenat ispitanika } & \multicolumn{3}{c|}{ U odnosu na } \\
& DA & NE & Vlasništvo & Veličinu & $\begin{array}{c}\text { Način } \\
\text { poslovanja }\end{array}$ \\
\hline Da li su svi zaposleni bili na poslu? & $41,7 \%$ & $58,3 \%$ & $\mathbf{0 , 0 0 2}$ & $\mathbf{0 , 0 0 3}$ & $\mathbf{0 , 0 1 6}$ \\
\hline Da li je deo zaposlenih radio od kuće? & $41,7 \%$ & $58,3 \%$ & $\mathbf{0 , 0 0 8}$ & $\mathbf{0 , 0 0 4}$ & $\mathbf{0 , 0 3 1}$ \\
\hline Da li su zaposleni koristili godišnje odmore? & $83,3 \%$ & $16,7 \%$ & 0,168 & $\mathbf{0 , 0 0 0}$ & $\mathbf{0 , 0 0 6}$ \\
\hline Da li su zaposleni imali neplaćeno odsustvo? & $100 \%$ & $0 \%$ & - & - & - \\
\hline $\begin{array}{l}\text { Da li su zaposleni radili nepuno radno } \\
\text { vreme? }\end{array}$ & $66,7 \%$ & $33,3 \%$ & 0,958 & 0,102 & 0,460 \\
\hline Da li je smanjen broj zaposlenih? & $25,0 \%$ & $75,0 \%$ & $\mathbf{0 , 0 0 0}$ & 0,054 & $\mathbf{0 , 0 4 8}$ \\
\hline Da li je povećan broj zaposlenih? & $8,3 \%$ & $91,7 \%$ & 0,646 & $\mathbf{0 , 0 1 9}$ & 0,566 \\
\hline
\end{tabular}

Analiza osnovnih podataka o načinu funkcionisanja preduzeća tokom pandemije COVID-19 urađena je primenom hi-kvadrat testa nezavisnosti. $U$ zavisnosti od vlasničke strukture preduzeća, utvrdili smo da su zaposleni koji rade u preduzećima sa privatnim kapitalom u značajno većem broju bili na poslu (chi-square=12,735; $d f=2 ; p=0,002$ ), i da nisu radili od kuće (chi-square $=9,687 ; d f=2 ; p=0,008$ ) $u$ poređenju sa zaposlenim u preduzećima s državnim kapitalom. Takva preduzeća nisu smanjivala broj zaposlenih (chi-square=21,486; $d f=2 ; p=0,000$ ) za razliku od preduzeća s državnim kapitalom.

U zavisnosti od veličine preduzeća, utvrdili smo da su zaposleni koji rade u mikro preduzećima (od 1 do 5 zaposlenih) u značajno većem broju bili na poslu (chi-square=11,585; $d f=2 ; p=0,003$ ), nisu radili od kuće (chi-square $=11,085 ; d f=2 ; p=0,004$ ) u odnosu na mala i srednja preduzeća. Kod mikro preduzeća zaposleni su manje koristili godišnji odmor (chisquare $=16,000 ; d f=2 ; p=0,000$ ) i nije povećavan broj zaposlenih (chi-square=7,957; $d f=2 ; \quad p=0,019$ ) $u$ odnosu na mala, a naročito u odnosu na srednja preduzeća.

U zavisnosti od načina poslovanja, utvrdili smo da kod preduzeća gde preduzetnici rade samostalno sa članovima svoje porodice u značajno većem broju su bili na poslu (chi-square $=5,744 ; d f=1 ; p=0,016$ ) i nisu radili od kuće (chi-square $=3,696 ; d f=1 ; p=0,019$ ) u poređenju sa preduzećima koja imaju zaposlene. Takva preduzeća nisu smanjivala broj zaposlenih (chi-square=2,695; $d f=1 ; p=0,048$ ) u odnosu na preduzeća koja imaju zaposlene koja su u značajno većem broju koristili godišnji odmor (chi-square= $7,301 ; d f=1 ; p=0,006)$.

Drugi deo upitnika odnosi se na glavne probleme i izazove sa kojima su se preduzeća suočavala usled krize izazvane pandemijom COVID-19. Ovaj deo upitnika se sastoji od sedam pitanja i stavovi ispitanika iskazani na ova pitanja su prikazani su na Likertovoj skali i analizirani u odnosu na vlasništvo nad preduzećem i veličinu preduzeća. Dobijeni rezultati su prikazani u Tabeli 2. 
Tabela 2. Glavni problemi i izazovi sa kojima su se preduzeća suočavala usled pandemije COVID-19

Table 2. The main problems and challenges faced by companies due to the pandemic COVID-19

\begin{tabular}{|l|c|c|c|c|c|c|c|}
\hline \multicolumn{1}{|c|}{ Pitanje } & \multicolumn{3}{c|}{ Procenat ispitanika } & \multicolumn{3}{c|}{ U odnosu na } \\
& 1 & 2 & 3 & 4 & 5 & Vlasništvo & Veličinu \\
\hline $\begin{array}{l}\text { Da li je promet dovoljan za servisiranje tekućih obaveza } \\
\text { poslovanja? }\end{array}$ & - & 20,8 & 27,1 & 33,3 & 18,8 & 0,217 & $\mathbf{0 , 0 0 1}$ \\
\hline $\begin{array}{l}\text { Da li su poslovni partneri/klijenti pogođeni posledicama } \\
\text { krize i da li im je otežano poslovanje? }\end{array}$ & - & - & 16,7 & 50,0 & 33,3 & 0,696 & 0,851 \\
\hline Da li se potražnja za robom/uslugama smanjila? & - & - & 16,7 & 47,9 & 35,4 & 0,120 & 0,202 \\
\hline Da li je bilo prekida u radu kompanije? & 25,0 & 8,3 & 16,7 & 8,3 & 41,7 & $\mathbf{0 , 0 3 6}$ & 0,146 \\
\hline $\begin{array}{l}\text { Da li su zaposleni odsustvovali sa posla zbog epidemije i } \\
\text { Vladinih mera? }\end{array}$ & 16,7 & 8,3 & 8,3 & 16,7 & 50,0 & 0,121 & $\mathbf{0 , 0 0 1}$ \\
\hline $\begin{array}{l}\text { Da li je bilo problema sa nabavkom sirovina ili rastom } \\
\text { cena sirovina? }\end{array}$ & - & - & 8,3 & 75,0 & 16,7 & 0,879 & 0,052 \\
\hline Da li su dobavljači operativni? & 16,7 & 8,3 & 16,7 & 50,0 & 8,3 & 0,115 & 0,518 \\
\hline
\end{tabular}

Analiza glavnih problema i izazova sa kojima su se preduzeća suočavala usled krize izazvane pandemijom COVID-19 urađena je primenom jednofaktorske ANOVA za različite grupe sa naknadnim testovima, odnosno t testa za nezavisne uzorke. U odnosu na vlasništvo nad preduzećem, utvrdili smo da postoji statistički značajna razlika $F(2 ; 45)=3,573 ; p=0,036) \mathrm{u}$ tvrđenjima da je bilo prekida u radu kompanije između preduzeća sa privatnim $(M=3,00)$ i onih sa mešovitim kapitalom $(M=4,71)$, što je prikazano na Grafikonu 1.

U odnosu na veličinu preduzeća, utvrdili smo da postoji statistički značajna razlika $(F(2 ; 45)=7,796$; $\mathrm{p}=0,001)$ u stavovima da promet nije dovoljan za servisiranje tekućih obaveza poslovanja i to između mikro preduzeća $(M=4,17)$ i malih $(M=3,15)$ i srednjih preduzeća $(\mathrm{M}=3,06)$. Takođe, utvrdili smo da postoji statistički značajna razlika $(F(2 ; 45)=7,741 ; p=0,001)$ u tvrđenjima da su zaposleni bili odsutni zbog epidemije i Vladinih mera i to između mikro preduzeća $(M=2,83)$ i srednjih preduzeća $(M=4,65)$, što je prikazano na Grafikonima 2 i 3.

Treći deo upitnika odnosi se na načine na koje je pandemija COVID-19 uticala na rad kompanija. Ovaj deo upitnika se sastoji od šest pitanja i odgovori ispitanika na ova pitanja su analizirani u odnosu na vlasništvo nad preduzećem, veličinu preduzeća kao i način poslovanja. Rezultati su prikazani u Tabeli 3.

Tabela 3. Načini na koje je pandemija virusa COVID-19 uticala na rad kompanija

Table 3. The ways in which the COVID-19 virus pandemic affected the work of companies

\begin{tabular}{|c|c|c|c|c|}
\hline \multirow{2}{*}{ Pitanje } & \multicolumn{2}{|c|}{ Procenat ispitanika } & \multicolumn{2}{|c|}{ U odnosu na } \\
\hline & DA & $\mathrm{NE}$ & Vlasništvo & Veličinu \\
\hline $\begin{array}{l}\text { Da li ste morali da obustavite poslovanje, da prekinete svaku } \\
\text { aktivnost jer je delatnost firme privremeno obustavljena } \\
\text { uredbom Vlade }\end{array}$ & 58,3 & 41,7 & 0,002 & 0,003 \\
\hline $\begin{array}{l}\text { Da li ste odlučili da privremeno zatvorite firmu iako delatnost } \\
\text { nije obustavljena merama Vlade, kako bi ostvarili pravo na } \\
\text { olakšice u plaćanju poreza i doprinosa }\end{array}$ & 8,3 & 91,7 & 0,646 & 0,019 \\
\hline $\begin{array}{l}\text { Da li ste morali da smanjite obim aktivnosti, ali ste još uvek } \\
\text { uspevali da poslujete }\end{array}$ & 91,7 & 8,3 & 0,646 & 0,019 \\
\hline Da li ste imali poteškoća da dođete do sirovina, repromaterijala & 83,3 & 16,7 & 0,168 & 0,987 \\
\hline Da li ste imali poteškoća u isporučivanju robu na tržište & 66,7 & 33,3 & 0,122 & 0,167 \\
\hline $\begin{array}{l}\text { Da li ste morali da obustavite ili smanjite obim poslovanja zbog } \\
\text { toga što zaposleni nisu mogli da dolaze na posao }\end{array}$ & 41,7 & 58,3 & 0,000 & 0,000 \\
\hline
\end{tabular}

Analizu načina na koji je pandemija COVID-19 uticala na rad kompanija urađena je primenom hikvadrat testa nezavisnosti. Utvrdili smo da su vlasništvo nad preduzećem i tvrdnje "Morali smo da obustavimo poslovanje" (chi-square $=12,735$; $d f=2$; $p=0,002)$ i "Morali smo da obustavimo ili smanjimo obim poslovanja" (chi-square $=24,960 ; d f=2 ; p=0,000$ ) zavisna obeležja. Poslovanje su u značajno većem broju morala da obustave, kao i da obustave ili smanje obim poslovanja, preduzeća s državnim i mešovitim kapitalom u odnosu na preduzeća s privatnim kapitalom, što je prikazano na Grafikonima 4 i 5. 
Takođe smo utvrdili da su veličina preduzeća i tvrdnje "Morali smo da obustavimo poslovanje" (chisquare $=11,585 ; \mathrm{df}=2 ; p=0,003$ ), "Odlučili smo da privremeno zatvorimo firmu" (chi-square $=7,957$; $\mathrm{df}=2$; $p=0,019$ ), "Morali smo da smanjimo obim aktivnosti, ali još uvek poslujemo" (chi-square $=7,957$; $d f=2$; $\mathrm{p}=0,019$ ) i "Morali smo da obustavimo ili smanjimo obim poslovanja" (chi-square $=18,237 ; \mathrm{df}=2 ; \mathrm{p}=0,000$ ) zavisna obeležja. Poslovanje su u značajno većem broju morala da obustave srednja preduzeća, tj. ovaj rizik raste s veličinom preduzeća, što je prikazano na Grafikonu 6. Takođe, odluku o tome da privremeno zatvore firmu su u značajno većem broju donela srednja preduzeća, što je prikazano na Grafikonu 7. Smanjenje obima proizvodnje se u značajno većem broju dešavalo kod mikro i malih preduzeća, dok su firme koje su morale da obustave ili smanje obim proizvodnje u značajno većem broju srednja preduzeća i ovaj rizik raste $s$ veličinom preduzeća, što je prikazano na Grafikonima 8 i 9.

Četvrti deo upitnika odnosi se na percepciju mera potrebnih da bi se sanirale negativne posledice pandemije COVID-19 na preduzeća, odnosno biznis. Ovaj deo upitnika se sastoji od pet pitanja i stavovi ispitanika iskazani su na Likertovoj skali i analizirani u odnosu na vlasništvo nad preduzećem, veličinu preduzeća kao i način poslovanja. Dobijeni rezultati su prikazani u Tabeli 4.

Tabela 4. Percepcija mera potrebnih da bi se sanirale posledice pandemije COVID-19 na preduzeća Table 4. Perception of the measures needed to remedy the effects of the COVID-19 pandemic on enterprises

\begin{tabular}{|l|c|c|c|c|c|c|c|c|}
\hline \multicolumn{1}{|c|}{ Pitanje } & \multicolumn{3}{c|}{ Procenat ispitanika } & \multicolumn{4}{c|}{ U odnosu na } \\
& 1 & 2 & 3 & 4 & 5 & Vlasništvo & Veličinu & $\begin{array}{c}\text { Način } \\
\text { poslovanja }\end{array}$ \\
\hline $\begin{array}{l}\text { Da li poreske olakšice mogu sanirati } \\
\text { posledice pandemije? }\end{array}$ & - & - & 2,1 & 39,6 & 58,3 & 0,548 & 0,658 & 0,809 \\
\hline $\begin{array}{l}\text { Da li otipisivanje poreza i doprinosa } \\
\text { za period vanrednog stanja ili do } \\
\text { kraja godine mogu sanirati } \\
\text { posledice pandemije? }\end{array}$ & - & - & 2,1 & 43,8 & 54,2 & 0,072 & $\mathbf{0 , 0 4 3}$ & $\mathbf{0 , 0 1 2}$ \\
\hline $\begin{array}{l}\text { Da li neka finansijska podrška može } \\
\text { sanirati posledice pandemije? }\end{array}$ & - & - & 6,3 & 37,5 & 56,3 & 0,715 & 0,595 & 1,000 \\
\hline $\begin{array}{l}\text { Da li davanje bespovratnih } \\
\text { finansijskih sredstava/subvencija } \\
\text { mogu sanirati posledice pandemije? }\end{array}$ & - & - & 8,3 & 35,4 & 56,3 & 0,136 & $\mathbf{0 , 0 3 9}$ & 0,080 \\
\hline $\begin{array}{l}\text { Da li davanje povoljnijh bankarskih } \\
\text { kredita sa dužim periodom otplate } \\
\text { mogu sanirati posledice pandemije? }\end{array}$ & - & - & 18,8 & 22,9 & 58,3 & 0,273 & 0,442 & 0,175 \\
\hline
\end{tabular}

Analiza percepcije mera potrebnih da bi se sanirale posledice pandemije COVID-19 na preduzeća, odnosno biznis urađena je primenom jednofaktorske ANOVA za različite grupe sa naknadnim testovima, odnosno t testa za nezavisne uzorke. Utvrdili smo da postoji statistički značajna razlika stavova "Otpisivanje poreza i doprinosa za period vanrednog stanja ili do kraja godina" $(F(2 ; 45)=3,379 ; p=0,043)$ kao i "Davanje bespovratnih finansijskih sredstava/subvencija" $(F(2 ; 45)=3,483 ; p=0,039)$ u odnosu na veličinu preduzeća. Statistički značajna razlika u stavovima o otpisivanju poreza i doprinosa za vreme vanrednog stanja ili do kraja godine postoji konkretno između mikro $(M=4,72)$ i malih preduzeća $(M=4,23)$ što je prikazano na Grafikonu 10. Takođe, značajna razlika između mikro $(M=4,78)$ i malih $(M=4,23)$ preduzeća postoji i u stavovima o davanju bespovratnih finansijskih sredstava/subvencija što je prikazano na Grafikonu 11.

Utvrdili smo i da postoji statistički značajna razlika u stavovima o "Otpisivanje poreza i doprinosa za period vanrednog stanja ili do kraja godina" $(\mathrm{t}=2,621$; $d f=46 ; p=0,012)$ u odnosu na način poslovanja. Pozitivniji stav o ovoj meri imaju preduzeća u kojima preduzetnici rade samostalno sa svojim porodicama $(\mathrm{M}=4,90)$ u odnosu na preduzeća koja zapošljavaju radnike $(M=4,42)$ što je prikazano na Grafikonu 12.

Peti deo upitnika odnosi se na pad profita preduzeća na godišnjem nivou, izražen u dinarima, nastao usled pandemije COVID-19.

Analizom profita preduzeća, očigledno da je kod svih preduzeća došlo do pada profita usled pandemije COVID-19, što je prikazano u tabeli 5. Preko polovine analiziranih preduzeća, imalo je pad profita do 20.000 dinara na godišnjem nivou, dok je manje od $10 \%$ imalo pad od preko pola miliona dinara. Iz priloženih rezultata vidimo da se pandemija COVID19 uzrokovala značajan pad profita preduzeća u Republici Srbiji, kao i da je značajno uticala na način poslovanja preduzeća, čime je dokazana osnovna hipoteza ovog rada. 
Tabela 5. Pad profita preduzeća na godišnjem nivou tokom pandemije COVID-19 (RSD)

Table 5. Falling corporate profits on an annual basis during the COVID-19 pandemic (RSD)

\begin{tabular}{|l|c|c|c|c|c|}
\hline & $\begin{array}{c}\text { Do 5.000 } \\
\text { RSD }\end{array}$ & $\begin{array}{c}5.000-20.000 \\
\text { RSD }\end{array}$ & $\begin{array}{c}20.000-100.000 \\
\text { RSD }\end{array}$ & $\begin{array}{c}100.000-500.000 \\
\text { RSD }\end{array}$ & $\begin{array}{c}\text { Preko } 500.000 \\
\text { RSD }\end{array}$ \\
\hline $\begin{array}{l}\% \text { ispitanih } \\
\text { preduzeća }\end{array}$ & $35,4 \%$ & $20,8 \%$ & $16,7 \%$ & $18,8 \%$ & $8,3 \%$ \\
\hline
\end{tabular}

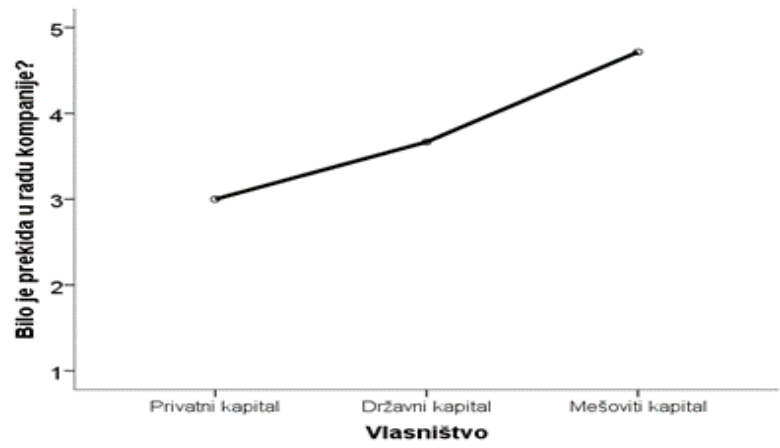

Grafikon 1. Analiza glavnih problema u odnosu na vlasništvo

Graph 1. Analysis of the main problems in relation to ownership

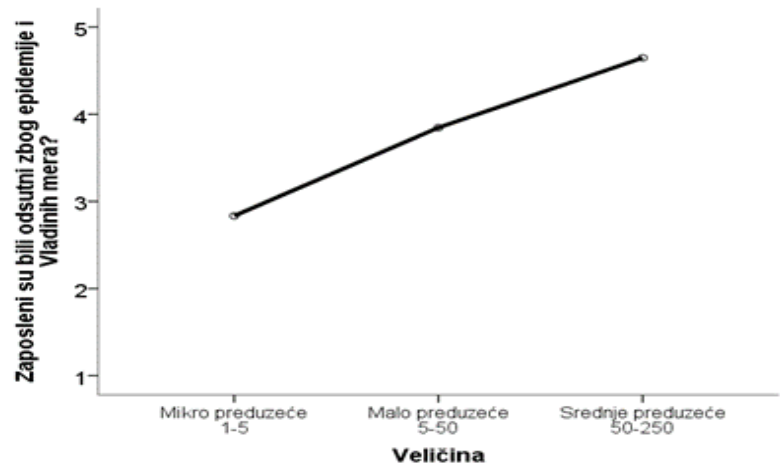

Grafikon 3. Analiza glavnih problema u odnosu na veličinu preduzeća (II)

Graph 3. Analysis of the main problems in relation to the size of the company (II)

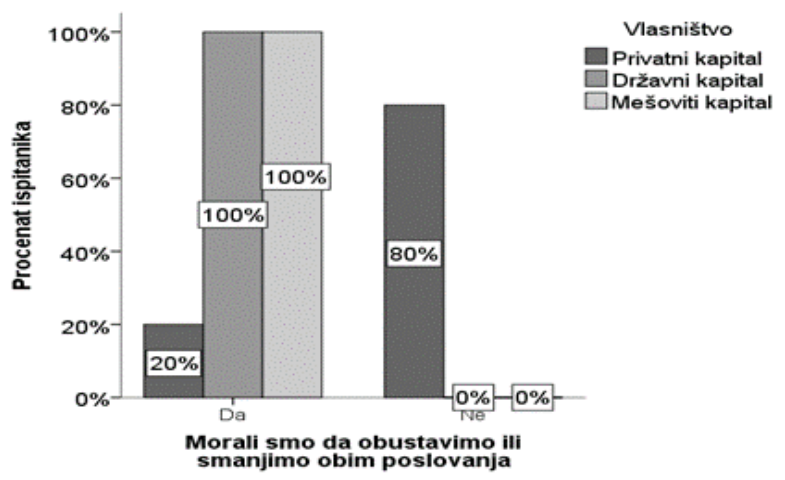

Grafikon 5. Uticaj pandemije u odnosu na vlasništvo preduzeća (II)

Graph 5. The impact of a pandemic on property of the company (II)

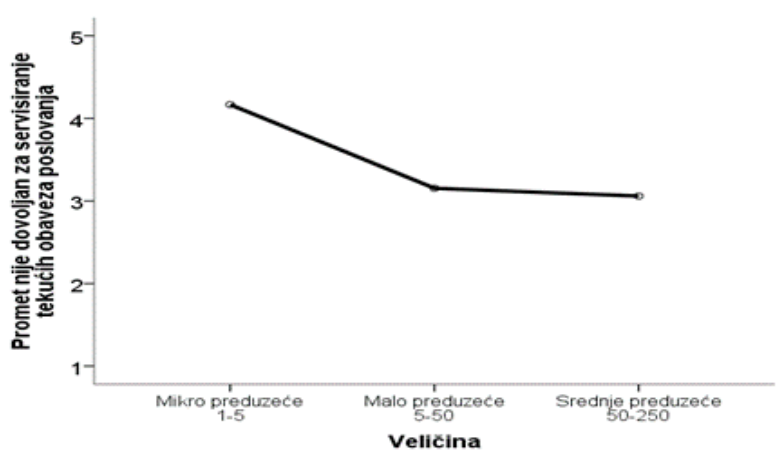

Grafikon 2. Analiza glavnih problema u odnosu na veličinu preduzeća (I)

Graph 2. Analysis of the main problems in relation to the size of the company (I)

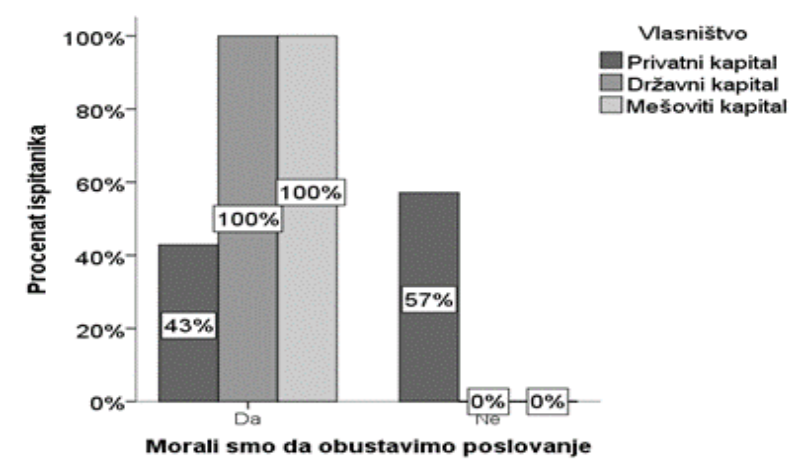

Grafikon 4. Uticaj pandemije u odnosu na vlasništvo preduzeća (I)

Graph 4. The impact of a pandemic on property of the company (I)

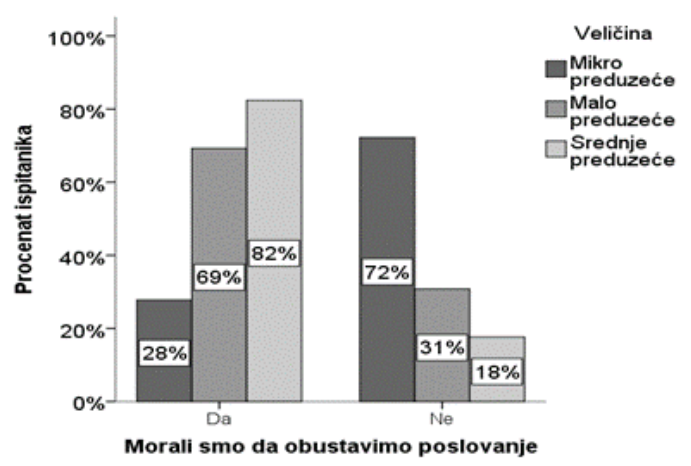

Grafikon 6. Uticaj pandemije u odnosu na veličinu preduzeća (I)

Graph 6. The impact of a pandemic in relation to the size of the company (I) 


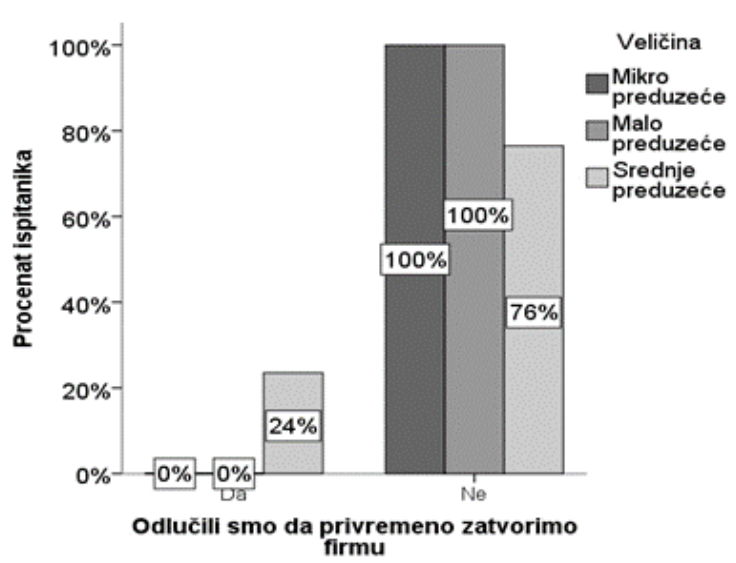

Grafikon 7. Uticaj pandemije u odnosu na veličinu preduzeća (II)

Graph 7. The impact of a pandemic in relation to the size of the company (II)

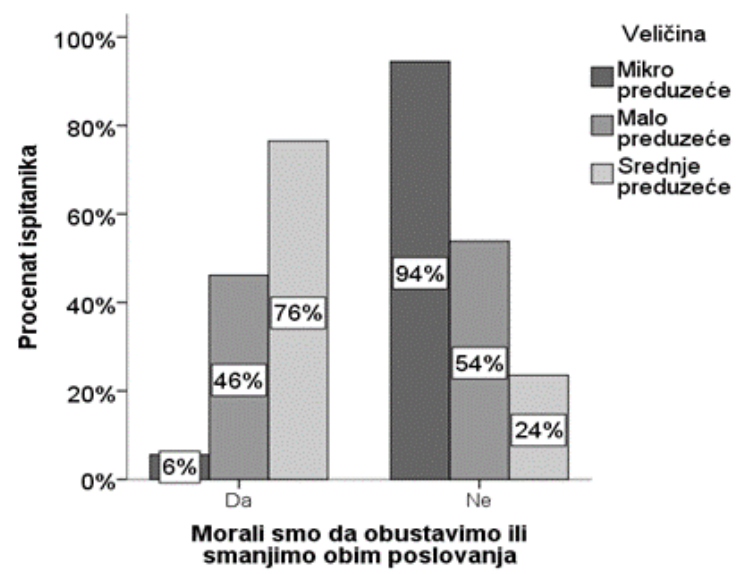

Grafikon 9. Uticaj pandemije u odnosu na veličinu preduzeća (IV)

Graph 9. The impact of a pandemic in relation to the size of the company (IV)

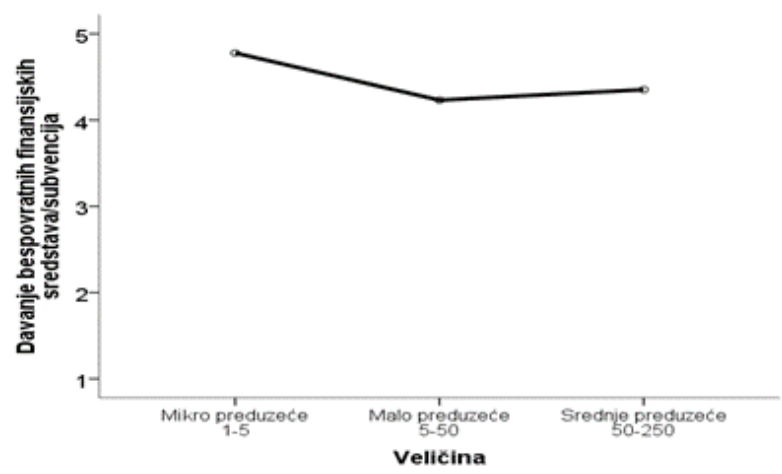

Grafikon 11. Mere sanacije u odnosu na veličinu preduzeća (II)

Graph 11. Remediation measures in relation to the size of the company (II)

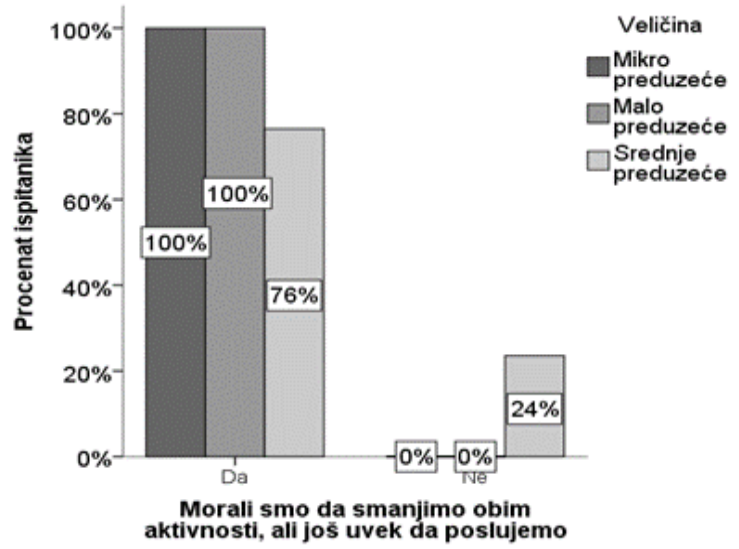

Grafikon 8. Uticaj pandemije u odnosu na veličinu preduzeća (III)

Graph 8. The impact of a pandemic in relation to the size of the company (III)

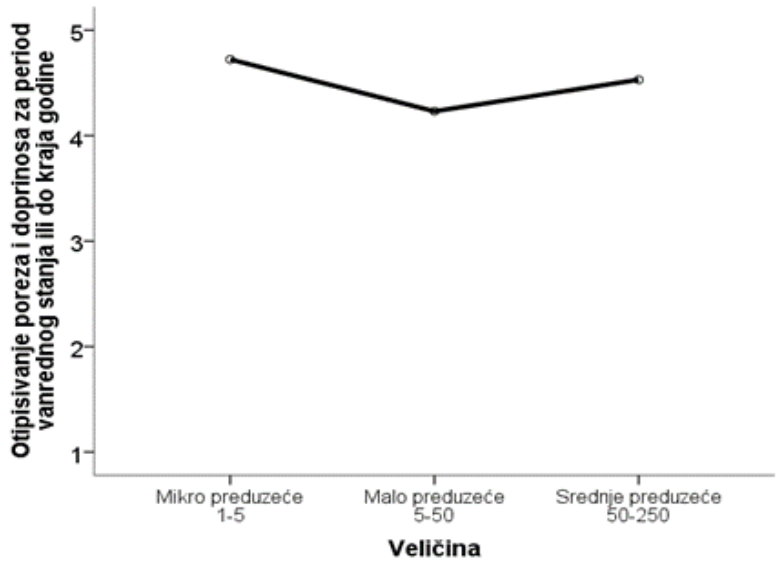

Grafikon 10. Mere sanacije u odnosu na veličinu preduzeća (I)

Graph 10. Remediation measures in relation to the size of the company (I)

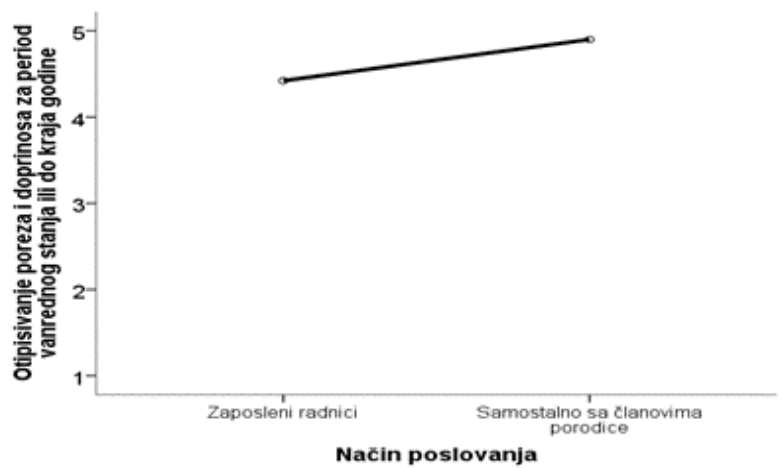

Grafikon 12. Mere sanacije u odnosu na način poslovanja

Graph 12. Remediation measures in relation to the way of doing business 


\section{ZAKLJUČAK / CONCLUSION}

Pandemija COVID-19 je u relativno kratkom vremenskom roku u Srbiji izmenila način na koji funkcionišu društveni, ekonomski i zdravstveni sistemi mnogih zemalja. Države širom sveta pa i Srbija su uvodile manje ili više rigorozne preventivne mere. Ove mere su donele promene za koje se predviđa da će zauvek promeniti način na koji će društvo i privredni subjekti funkcionisati. U proizvodnom sektoru kod mikro, malih i srednjih preduzeća se javlile problemi sa likvidnošću usled potrebe nabavke sirovina i repromaterijala za proizvodnju. Većina njih nema problem sa prometom, ali imaju problem sa likvidnošću. Ovoj grupi treba pomoći povoljnim kreditnim linijama i odlaganjem plaćanja poreza kako bi se održala likvidnost istih. Konačno, nisu ni svi sektori $u$ istoj meri pogođeni krizom, što ne znači da će, ukoliko ona potraje, neki biti pošteđeni.

Tokom pandemije COVID-19, preduzeća sa privatnim kapitalom uglavnom nisu obustavljala proizvodnju kao ni smanjivala obim poslovanja, dok su njihovi zaposleni radili tokom pandemije na radnom mestu. Mikro preduzeća, a tu su uglavnom preduzeća u kojima preduzetnici rade samostalno i sa članovima svojih porodica, su uglavnom imala problem, usled smanjenja obima proizvodnje, da im promet nije bio dovoljan za servisiranje tekućih obaveza poslovanja, dok su njihovi zaposleni uglavnom radili tokom pandemije na radnom mestu i nisu koristili godišnji odmor. Problem sa obustavom proizvodnje se uglavnom vezuje za srednja preduzeća i ovaj rizik raste sa veličinom preduzeća. Kao glavnu pomoć pri sanaciji proizvodnje mikro preduzeća, odnosno preduzeća u kojima preduzetnici rade samostalno i sa članovima svojih porodica, vide u otpisivanju poreza i doprinosa za vreme vanrednog stanja kao i u dobijanju bespovratnih finansijskih sredstava.

\section{LITERATURA / REFERENCES}

[1] Čavrak, V. (2020), Makroekonomija krize COVID19 i kako pristupiti njenom rješavanju. EFZG Working paper series, No. 03, 1-19.
[2] Duvnjak, V. (2018), Coping with Business Crisis in the EU Periphery: A Case of Bosnia and Herzegovina. Journal of Balkan and Near Eastern Studies, 20(2), 196-210.

[3] Duvnjak, V. (2020), Iznenadni događaj (CoVID19 pandemija) - uticaj na finansijsku krizu u preduzeću i prevredu u celini. Poslovne studije, 23-24, 43-49.

[4] Đurović, S., Perović, A., Šiljak, V., Antonijević, S., Veselinović, J., Baćevac, S. (2020). Održivost razvoja sportskog turizma kao privredne grane: uticaj COVID-19, Ecologica, 27(100), 699-706.

[5] Fornaro, L., Wolf, M. (2020), Coronavirus and macroeconomic policy, https://voxeu.org/article/ coronavirus-and-macroeconomic-policy, dostupno dana: 18.04.2021.

[6] Hale, T., Angrist, N., Kira, B., Petherick. A., Phillips, T., Webster. S. (2020), Variation in Government Responses to COVID-19. BSG Working Paper Series. BSG-WP-2020/032 Version 6.0.

[7] Jovanović, L., Ermakov, V. (2020), The role of trace elements in the prevention of viral diseases, Ecologica, 27(100), 565-571.

[8] Jovanović, V., Nikolić Tošović, M. (2021), Upravljanje preduzećem u doba pandemije COVID-19: izazovi za preduzetnike, mala i srednja preduzeća, Ecologica, 28(102), 151-157

[9] Prašćević, A. (2020), Ekonomski šok pandemije COVID-19 - prekretnica u globalnim ekonomskim kretanjima. Ekonomske ideje i praksa, 37, 7-22.

[10] Radoičić, J., Arsić, Lj. (2021), Sagledavanje posledica krize izazvane pandemijom COVID-19 na održivost preduzeća, Ecologica, 28(102), 243-249.

[11] Tripković, A., Arsić, Lj., Dobričanin, S. (2021), Izazov funkcionisanja i razvoja malih i srednjih preduzeća u cirkularnoj ekonomiji, Ecologica, 28 (101), 50-56.

[12] Živković, D., Petrović, P., Ercegović, M. (2020), Način finansiranja malih i srednjih preduzeća u hotelijerstvu i eko-turizmu, Ecologica, 27(97), 75-81. 